\title{
QUEEN'S
UNIVERSITY
BELFAST
}

\section{Active Controllers or Wealthy Rentiers?: Large Shareholders in Victorian Public Companies}

Acheson, G. G., Campbell, G., \& Turner, J. D. (2015). Active Controllers or Wealthy Rentiers?: Large Shareholders in Victorian Public Companies. Business History Review, 89(4), 661-691.

https://doi.org/10.1017/S0007680515001026

\section{Published in:}

Business History Review

\section{Document Version:}

Peer reviewed version

Queen's University Belfast - Research Portal:

Link to publication record in Queen's University Belfast Research Portal

Publisher rights

Copyright The President and Fellows of Harvard College 2016.

\section{General rights}

Copyright for the publications made accessible via the Queen's University Belfast Research Portal is retained by the author(s) and / or other copyright owners and it is a condition of accessing these publications that users recognise and abide by the legal requirements associated with these rights.

Take down policy

The Research Portal is Queen's institutional repository that provides access to Queen's research output. Every effort has been made to ensure that content in the Research Portal does not infringe any person's rights, or applicable UK laws. If you discover content in the Research Portal that you believe breaches copyright or violates any law, please contact openaccess@qub.ac.uk. 


\title{
Active Controllers or Wealthy Rentiers? Large Shareholders in Victorian Public Companies
}

\begin{abstract}
:
This article addresses the issue of whether large shareholders in Victorian public companies were active in the control of companies or were simply wealthy rentiers. Using ownership records for 890 firm-years, we examine the control rights, sociooccupational background, and wealth of large shareholders. We find that many large shareholders had limited voting rights and neither they nor family members were directors. This implies that the majority of public companies in the second half of the nineteenth century cannot be characterized as family companies and that large shareholders are better viewed as wealthy gentlemen capitalists rather than entrepreneurs.
\end{abstract}

\section{Published:}

Graeme G. Acheson, Gareth Campbell and John D. Turner (2015). Active Controllers or Wealthy Rentiers? Large Shareholders in Victorian Public Companies. Business History Review, 89, pp 661-691. doi:10.1017/S0007680515001026.

(http://dx.doi.org/10.1017/S0007680515001026) 
One of the big questions in the historical evolution of the public corporation is this: When did ownership separate from control? The received view among business historians until recently was that when incorporation laws were liberalized in the nineteenth century, the ownership of corporations was dominated by founding families, but as public corporations grew in scale in the twentieth century, ownership became more dispersed. ${ }^{1}$ This view has recently been challenged and has subsequently generated substantial debate among scholars. ${ }^{2}$ In this article, we contribute to this debate by analyzing large shareholders in Victorian public companies formed after the liberalization of British incorporation law in $1856 .{ }^{3}$ In related work, we find that the broad structure of corporate ownership was surprisingly diffuse in the Victorian era. ${ }^{4}$ In this article, however, we examine in detail the largest shareholders in all of our sample firms to establish whether they played an active governance role in companies or were wealthy rentiers who simply provided finance to companies.

The acts that liberalized incorporation legislation in the United Kingdom required companies to report a detailed list of shareholders and their ownership to the Registrar of Companies on an annual basis. ${ }^{5}$ After a comprehensive archival search, we found ownership records for 488 unique companies and 890 company years for the second half of the nineteenth century. We define large shareholders as the largest owner in the company plus all others who own more than 10 percent of the company's voting or cash flow rights. In total, across the 890 company years, we have identified 1,158 unique large shareholders. In order to assess whether these large owners played a governance role or were simply wealthy rentiers, we use our ownership data to measure how much voting control large shareholders had. We then examine the socio-occupational background of these large shareholders and where they lived, to see if they had a background consistent with being a rentier rather than an active large owner. Finally, we attempt to establish the wealth of large shareholders using probate records. We do so for two reasons. First, if a large shareholder's ownership in a company is a substantial proportion of their wealth, this would imply that they exercised more control over the company because a large proportion of family wealth was at stake. Second, if a shareholder was a rentier, we want to see if they were from the super-rich elite or from the moderately wealthy middle class. 
A study of large shareholders in Victorian Britain is of interest for at least one additional reason. The rapid expansion of both the U.K. equity market and the investing public during the latter part of the nineteenth century may have been facilitated by the control exercised by large owners acting to assure smaller shareholders that managers would act in their (the shareholders') interests. ${ }^{6}$

Taking our evidence as a whole, our main finding is that large owners in general do not appear to have exercised much control over the companies in which they were large shareholders. Rather, our evidence suggests that large shareholders in many Victorian companies were merely wealthy investors. This finding - that the average large shareholder did not appear to exercise much control - is consistent with Colin Mayer's view that by giving up control, large owners are credibly committing to other parties who contract with the firm, particularly other investors, that they will not abuse their power to expropriate other stakeholders. ${ }^{7}$ Notably, Eric Hilt and Aldo Musacchio argue that something similar occurred in the early development of the U.S. and Brazilian equity markets. ${ }^{8}$

This article contributes to a strand of business history literature that has criticized the control of British companies in the Victorian and Edwardian eras. Following Alfred Chandler, the commonly accepted view is that British firms, when they were established in the nineteenth century, were family controlled and that this persisted into the twentieth century, with the result that they did not develop the managerial sophistication of their U.S. counterparts. ${ }^{9}$ This state of affairs may ultimately have played a role in the relative decline of the British economy in the twentieth century. ${ }^{10}$ However, our findings suggest that this view needs some revision because the degree to which large shareholders or families controlled the vast majority of companies in our sample is debatable.

This article also builds on the growing literature on investors in the Victorian era. To date, this literature has focused on sociocultural references and public perception of investors; investors in banks, gas companies, and railways; and the relationship between gender and investment. ${ }^{11} \mathrm{We}$ augment this literature by looking solely at large shareholders across a wide variety of industries in the second half of the nineteenth century. ${ }^{12}$ 
Finally, this article contributes to the debate regarding the role of the city's capital markets in channeling capital to colonial or overseas companies to the detriment of indigenous British firms. ${ }^{13}$ Our study enables us to add several nuances to this debate because 155 of the 488 companies in our sample are overseas companies, enabling us to see the differences (if they exist) in control by, and identity of, large shareholders.

\section{Data on Large Shareholders}

The Companies Acts of 1856 and 1862 liberalized U.K. incorporation law by permitting entrepreneurs to incorporate with limited liability simply by registering with the Registrar of Companies. ${ }^{14}$ Companies registered under these acts were required annually to return a list of their ordinary and, where applicable, preference shareholders to the Registrar of Companies using a standardized return form known as Form E. These returns always contained the shareholder's name and the number of shares owned, and, in the majority of cases, they also contained the shareholder's address and occupation. The returns of companies that were dissolved before 1970 were placed within the Companies Registration Office files at the National Archives at Kew (BT31 series) and the National Archives of Scotland (BT2 series).

We searched the catalogues of the BT2 and BT31 series for public companies that had issued common stock quoted either in the Course of the Exchange between 1825 and 1870 or in the Investor's Monthly Manual in 1870, 1885, and $1899 .{ }^{15}$ Our final sample consists of 890 firm-years, representing 488 unique companies. ${ }^{16}$ Of these companies, 333 were domestic companies and 155 can be defined as overseas companies, since their operations were based outside of the British Isles. Information on the location of a company's main operations was obtained from memoranda of association contained with the files in the BT31 and BT2 series, Burdett's Official Intelligence, Stock Exchange Official Intelligence, and Stock Exchange Year-book.

Because the ownership archives consist of companies that became defunct at some stage before 1970, none of our sample companies are still in existence today as separate entities. Using the Register of Defunct Companies, we were able to trace the ultimate fate of most of our sample companies. About 55 percent became defunct because 
they reconstructed or merged with another firm, while approximately a further 28 percent of sample companies were liquidated. Most of the banks and insurance companies in our sample merged with the banks that dominate these sectors today. Notably, the Clydesdale Bank is in our sample and, although it merged with the Midland Bank in 1920, it has continued to operate under its original name. Other companies in our sample merged to form industrial giants. For example, one of our sample companies, the Runcorn Soap and Alkali Company, merged with a group of other chemical companies to form United Alkali Company, which later merged with three other companies in 1926 to form Imperial Chemical Industries. Notably, the brand names associated with several sample companies that merged with other companies still exist today (e.g., Bovril and Schweppes).

In Table 1, we see that our sample contains a range of companies from different industries. Based on Richard Grossman's data on the industrial composition of the British capital market in this era, the one industry that is underrepresented is mining. ${ }^{17} \mathrm{We}$ found that the ownership records for mining companies were more likely to be missing or incomplete, possibly because of their short-lived and speculative nature. The commercial and industrial sector is the largest, which is unsurprising since this was a growth sector in the stock market between 1860 and $1900 .{ }^{18}$ This sector consisted mainly of manufacturing and processing companies (e.g., oil, petroleum, nitrate chemicals, fertilizer, soap and alkali, railway carriages and rolling stock, bicycles, paper mills, plate glass, dairies, wagons), but also contained some large retailers, publishers, and hotels. As can be seen in Table 1, our sample is spread across time, with just over half of our sample firm-years concentrated in the 1880s and 1890s.

\section{[INSERT TABLE 1]}

A question arises as to the representativeness of our sample and whether our sample composition is likely to bias our findings in one direction or another. As ownership data was not collected by the Registrar of Companies on statutory companies set up prior to 1862 (e.g., railways and other utilities), nor on banks and insurance companies (unless they registered under the 1862 Companies Act), our sample does not 
contain the largest companies in the Victorian era. Indeed, none of our companies would have made it into the top one hundred largest public companies in the year for which we have their ownership records; only 8.8 percent of our companies were in the top two deciles of non-railway companies in terms of their size and 63.3 percent of our companies were in the bottom half of non-railway companies in terms of their size. Thus, the vast majority of our sample consists of small and medium-sized public companies, which immediately biases our findings as such companies were more likely to have had large owners who exercised a substantial degree of control over their firms.

In terms of stock exchanges, we have information from the Investor's Monthly Manual on where the majority of our company's securities were traded. The percentages of sample companies traded on particular stock markets were as follows: Aberdeen (4.5), Birmingham (5.5), Bristol (2.4), Cardiff (0.8), Dublin (1.0), Dundee (4.6), Edinburgh (10.3), Glasgow (9.8), Leeds (3.5), Liverpool (8.0), London (33.8), Manchester (7.7), Newcastle (2.4) and Sheffield (5.5). ${ }^{19}$ Therefore, it is apparent that our sample does not have an exclusive focus on London and there is a wide geographic distribution in terms of where securities were traded. ${ }^{20}$

As we are interested in the voting rights as well as cash flow rights of large owners, we collected data on each company's voting scales for each year for which they are in our sample from their articles of association (contained within the files in the BT31 and BT2 series), Burdett's Official Intelligence (BOI), and Stock Exchange Official Intelligence (SEOI). These data were then used to calculate each shareholder's voting rights. We found the voting structures for 729 of the 890 firm-years of ownership returns.

As we are also interested in whether large shareholders were directors and whether they lived in close proximity to the companies in which they were large shareholders, we collected the names of directors and company headquarters for the relevant years from a combination of articles of association, BOI, SEOI, and Stock Exchange Year-book. In total, we located director names and company headquarters for 575 of the 890 firm-years in our sample.

As stated above, we define a large shareholder as the largest shareholder in the company plus anyone who owned more than 10 percent of voting or cash flow rights. We chose 10 percent to define large shareholders following the usual convention in the extant 
literature. ${ }^{21}$ If two or more individuals are joint owners of the largest stake or 10 percent of voting or cash flow rights, then we consider each of those individuals as large owners. After using our digitized ownership returns to identify large shareholders, we then went to the original photographs to transcribe their names, addresses, and occupations. In total, we have 1,158 large shareholders in our sample, with 111 of those being joint owners. Of the 111 joint owners, 29 share a common surname with their co-owners, implying a familial relationship.

\section{Control Exercised by Large Shareholders}

Companies in Victorian Britain raised capital by issuing ordinary and preference shares as well as debentures. ${ }^{22}$ The voting rights attached to preference shares were sometimes the same as for ordinary shares, but the usual practice was to assign preference shareholders voting rights under certain conditions, such as on reduction or increase of capital, on winding up of the company, or if the dividend on preference shares was in arrears. Debenture holders only exercised control whenever the company failed to make its coupon payments.

Table 2 contains statistics on the percentage of capital and voting rights owned by the largest shareholder in each firm-year. These figures contain ordinary and, if the company issued them, preference shares. In addition, the voting rights take account of whether or not preference shares had unconditional voting rights attached to them. In terms of the statistics for the overall sample, we see that the median largest shareholder owned 6.8 percent of capital and 4.9 percent of voting rights. To give some perspective on these figures, Rafael La Porta, Florencio Lopez-de-Silanes, and Andrei Shleifer suggest that a company has an ultimate owner (i.e., concentrated ownership) if the largest owner controls more than 20 percent of voting rights. ${ }^{23}$ They also have a weaker definition, where an ultimate owner is defined as having more than 10 percent of voting rights. Thus, no matter which definition of theirs we use, we can see that the median company in our sample did not have an ultimate owner.

[INSERT TABLE 2] 
As can be seen in Table 2, unlike in later eras, the voting rights of large shareholders in Victorian companies were generally lower than their cash flow rights. This was due to the popularity of voting scales, which penalized large investors and empowered smaller investors. For example, many companies had voting scales that placed an upper limit on the maximum number of votes that any one investor could have and/or a nonlinear voting scale skewed against large owners. ${ }^{24}$

As can be seen in Panel A of Table 2, which contains statistics on the largest owners by industry, there are few industries in which the median largest owner has close to or over 10 percent of voting rights. In three major industries, the median largest owner had the highest capital and voting rights: breweries; spinning and weaving; and iron, coal, and steel. One of the key differences between these three industries and others in Table 2 is that the former were established firms, with a partnership organizational form in place before they became public companies. In each of these industries, partnerships converted to limited companies in order to raise capital from the public to finance their growth in firm scale which occurred in all of these industries. ${ }^{25}$ The increased capital needs of breweries arose from (a) technological changes that increased their optimal size and (b) their need to secure public houses following regulatory changes in licensing, which pushed up their cost. ${ }^{26}$ In terms of iron, coal and steel, changes in technical processes and the increased scale of steel production led these firms to seek capital on public markets. ${ }^{27}$ Similarly, the capital needs of the spinning and weaving sector arose from an increase in the scale of efficient production. ${ }^{28}$

Panel A of Table 2 also reveals that low percentages of voting rights were held by the median largest owner in banks, finance, insurance, and gas, light, and waterworks. The latter were public utilities, which typically had large capital needs. Banks, finance, and insurance companies typically structured their articles of association to ensure diffuse ownership, by restricting the amount of shares any one investor could own and/or by skewing their voting scales in favor of small investors. ${ }^{29}$ One reason for doing so was that such companies usually had uncalled capital or extended liability, and depositors and policyholders with these companies may have preferred to see the company's shares dispersed amongst many wealthy investors instead of sold to one large wealthy owner. ${ }^{30}$ 
Panel B of Table 2 reveals that there is very little difference, in terms of the percentage of shares owned by the largest shareholder, between British companies operating in the domestic market and those operating in foreign markets. Meanwhile, Panel $\mathrm{C}$ shows that as the mean and median percentage of capital owned by the largest shareholder fell during our sample period, the mean and median percentage of voting rights increased. The contrasting movements over time are simply the result of the increased usage of nonvoting preference shares, which enabled large shareholders to have a share of voting rights that exceeded their share of capital.

Although the largest shareholders held relatively small amounts of the voting rights in their companies, they may have been able to exercise de facto control of the company through being directors. As can be seen in Table 3-which shows the proportion of large shareholders who were also directors-there are 803 large shareholders of companies for which we have details on who the directors were; only 306 of these shareholders were directors. In other words, 61.8 percent of large shareholders in our sample period were not directly involved in their firm's governance. Given their large stakes, one would expect more large shareholders to play a governance role. One possible explanation for this finding is that the company was a family company that had been established by the largest shareholder, who managed it on a day-to-day basis; that shareholder could have exercised control without being a director if they had superior knowledge of the business and their own men on the board. In order to determine whether a company was a family company, we examine whether the large shareholder's surname was part of the company's name. In Table 3, we see that in only 80 instances out of 1,158 did the company's name contain a large shareholder's surname. Another way of assessing whether a company is a family firm is to ask whether other directors shared a surname with the large shareholders. ${ }^{31}$ As can be seen in Table 3, there were 113 cases (constituting 153 directors) where at least one director had the same surname as a large investor. However, in the 496 cases where the large shareholder was not a director, it was in only 54 instances that a director shared a surname with the large shareholder.

\section{[INSERT TABLE 3]}


Table 3 reveals interesting differences between sectors. In particular, companies where directors share the same surname as the large shareholder, and those where the company name contains the family name, are mainly in two sectors: breweries and commercial and industrial. Notably, companies in these two sectors mainly came to market in the 1880s and 1890s, which explains the patterns we see in Panel C.

Industries that were more likely to be located overseas had a lower propensity for large shareholders to be directors. Panel B verifies this, as it reveals that there are marked differences between domestic and foreign companies in terms of large shareholders being directors or having family members as directors. This may indicate that large shareholders in foreign-based companies were simply wealthy passive investors.

If large shareholders were founding entrepreneurs or part of the founding family, we would expect them to remain as large shareholders for a lengthy period of time. We exploit the fact that our dataset contains some multiple-firm-year observations to see whether or not there is much in the way of turnover of large shareholders. With an average of slightly over ten years between ownership censuses, we find that in 60.4 percent of cases there are changes in the identity of the large shareholder. Only in 11.3 percent of these cases does the new large shareholder have the same surname as the previous incumbent, and in 24.3 percent of these cases does the previous large owner remain as a shareholder. This implies significant turnover of large shareholders within our period and a very small proportion of large shareholders being replaced by family members.

Notably, the turnover of large shareholders was greater in foreign companies than in domestic companies (74.5 percent change in identity of large shareholder versus 55.5 percent), which is further evidence that large investors in foreign companies were passive investors. The four industries with the lowest turnover are breweries (46.2 percent); commercial and industrial (54.3 percent); iron, coal and steel (52.5 percent); and spinning and weaving (50.0 percent). Each of these industries was more likely to be founder or family controlled, so the lower turnover rate is unsurprising.

The overall picture that emerges from the analysis above is that the average large owner in the Victorian era had little in the way of control rights and did not play a governance role. However, towards the end of the nineteenth century the average 
shareholder had more in the way of control rights, and it appears that more of a governance role was played by large shareholders or their family members. These findings raise several questions. First, who founded companies in this era? Second, why was there a change in the degree of separation between ownership and control towards the end of the century? Third, given the absence of control by large shareholders, who managed companies?

Unlike most modern public companies, many companies that were floated in the Victorian era were floated from scratch. In other words, many stock market flotations were not conversions of previously established businesses, but new ventures that raised capital from the stock market at their inception. ${ }^{32}$ The founders, as such, were the promoters behind the business, but they did not necessarily invest heavily in the business or run the business once it was established. However, from the 1880s onwards, and particularly in the 1890s, business concerns were much less likely to launch from scratch and much more likely to be conversions of existing partnerships and private companies. ${ }^{33}$ Whenever these companies were floated on the stock market, their founders typically tried to maintain control by issuing preference shares and debentures. ${ }^{34}$ This explains why there is less of separation of ownership from control towards the end of our sample period.

In terms of who managed Victorian companies whenever large shareholders did not play a hands-on managerial role, general managers or managing directors under the oversight of a board of a directors did, which is contrary to Chandler's critique of latenineteenth-century British capitalism. This, in turn, raises questions about how shareholders ensured that managers and directors ran the firm in their interests in an era when shareholder protection laws were weak. Gareth Campbell and John Turner suggest that capital market discipline, the expectation that nearly all earnings would be paid out as dividends, local stock exchanges, and boards of directors may all have played a role in ameliorating the agency problem in this era. ${ }^{35}$ 
Having established that a majority of large shareholders owned a small proportion of voting rights and did not play a governance role, in this section we examine who large shareholders were. We do so primarily because we want to ascertain whether large shareholders had a background consistent with being a rentier rather than an active large owner.

Since the shareholder returns report socio-occupational status and the address of shareholders, we can get some idea of the backgrounds and geographical distribution of large investors. ${ }^{36}$ However, a caveat needs to be placed on using what was reported in the shareholder returns. A large number of males were recorded as "gentleman" or "esquire." Men described as such could easily have been active businessmen, financiers, or professionals, or retired from active business or professional life. ${ }^{37}$ Alternatively, they could have been members of the landed gentry or simply signaling their social status. However, several pieces of evidence suggest that the majority of cases where someone is described as a gentleman or esquire are either men retired from active life or landed gentry. The first piece of evidence is that gentlemen are much less likely than men of other socio-occupational groups to be directors; specifically, 32 percent of gentlemen are directors, whereas comparable figures for other groupings range from 48 to 64 percent. The second piece of evidence is that 46 percent of gentlemen live outside large towns or a metropolitan area, which gives some indication about the extent to which they were members of the landed gentry. ${ }^{38}$

Gentlemen are by far the largest socio-occupational category in Table 4. Most of these individuals are not large shareholders in family firms; only 4.0 percent share their name with the company's name, and only 12.7 percent share their surname with a director. In addition, only 32.2 percent of gentlemen large shareholders are directors, which is a substantially lower percentage than that of the two other major occupation categories in Table 4 -merchants (54.1 percent) and manufacturers (64.7 percent). All of this evidence would suggest that many gentlemen large shareholders were wealthy passive investors simply seeking a return on their investment. The high proportion of 
gentlemen among large investors in foreign companies adds further support to this contention.

\section{[INSERT TABLE 4]}

In terms of other classical rentier groups, a small proportion of large shareholders were from the nobility (Table 4). ${ }^{39}$ However, the average value of their holdings in domestic companies is much larger than that of large shareholders from other sociooccupational categories. The only instance of members of nobility being closely involved with the companies in which they were large shareholders is the case of the Wigan Coal and Iron Company, which was established by James Lindsay (Earl of Crawford and Balcarres) in 1865 to acquire collieries on the Wigan coalfield. When his son, Alexander Lindsay, succeeded to the earldoms in 1869 , he devoted a lot of his time to the running of the company. ${ }^{40}$

Recent scholarship has uncovered the extent to which women invested in the stock market in the nineteenth century. ${ }^{41}$ Interestingly, thirty-five large shareholders in our sample were women. ${ }^{42}$ One explanation for this may be that they held investments in family firms or invested jointly with a family member; however, only three women invested jointly with a family member, a further three were large shareholders in a firm where one director shared their surname, and only one was a large shareholder in a firm that contained her surname in its appellation. Thus, it appears that that vast majority of female large shareholders were wealthy investors, with no family interest in terms of the family that shared its surname with the company in which they invested. The other notable thing about women large investors is that they invested predominantly in domestic companies, which may reflect an aversion to risk or a local bias. ${ }^{43}$

Professionals (mainly doctors, engineers, and surgeons) and members of the legal profession were large shareholders in a wide variety of industries. In many instances, our evidence points to the fact that these were wealthy professionals who had a large stake without necessarily having a family or managerial interest in the company.

Financiers and bankers have come in for criticism, in that they failed British industry and entrepreneurs by not providing sufficient capital. ${ }^{44}$ However, sixty-eight of 
the large shareholders in our sample were from the finance sector-i.e., bankers, stockbrokers, and other finance professionals (e.g., actuaries, accountants) —and, as can be seen in Table 4, financiers were predominately large shareholders in domestic companies. Of the forty-one bankers, nineteen were large shareholders in banks, which is unsurprising. The other twenty-two, who were large shareholders in a range of companies (including iron, coal, and steel; breweries; and commercial and industrial companies), include the names of several notable bankers and banking dynasties: Grenfell, Glyn, Gurney, Hambro, Lloyd, Schroder, Stern, and Tiarks. In other words, even though city banks may have been conservative or risk averse when it came to lending to British industry, individual bankers within the City were not and were willing to provide large amounts of capital to British companies.

In Table 4, we see that on twenty-eight occasions, members of Parliament were large shareholders. ${ }^{45}$ Although these individuals are recorded as politicians in the shareholder returns, using the Dictionary of National Biography and other genealogical tools, we found occupations in twenty-two cases, with the most common occupations being manufacturer, banker, and barrister. At least nine were, or had formerly been, manufacturers, with the most notable being Joseph Chamberlain. Five were from banking, with Henry S. King, John Lubbock, and Alexander Matheson (of Jardine Matheson) being the most notable. William Quilter, who was a stockbroker and a founding director of the National Telephone Company, was a large shareholder in the Lion Fire Insurance Company. ${ }^{46}$

Manufacturers differ from other categories in Table 4 in that they make up an extremely small proportion of large shareholders in foreign companies. One explanation is that manufacturers were much more likely to be large shareholders in family firms or in firms where they played a governance role. Notably, in 38 out of 124 instances, large shareholders who were manufacturers had their surname in the company name. Furthermore, manufacturers were much more likely to be directors than were any other category in Table 4-64.0 percent of large shareholders who were manufacturers were also directors. A further piece of evidence that suggests manufacturers were intimately involved with the companies in which they were large shareholders is that they rarely were large shareholders in nonmanufacturing firms; in fact, only nineteen of them were, 
and most of those firms were financial companies. ${ }^{47}$ In some cases, a manufacturer may have had a large shareholding in a company because they had an interest in the industry. For example, Henry Bessemer, of Bessemer converter fame, was a large shareholder in Thames Plate Glass Company in 1865, which may have arisen from his innovations in the production of plate glass. ${ }^{48}$

When compared with manufacturers, merchants were much more likely to invest in foreign companies and less likely to play a governance role within their companies. They were also much more likely to be large shareholders in nonmanufacturing companies, with ninety-five of them being so. Merchants were mainly classified as such in the shareholder returns, but we also assigned others, such as contractors, to this category. One notable example is Thomas Brassey, the well-known civil engineering contractor, who was a large shareholder in the Central Argentine Land Company in $1870 .^{49}$

As can be seen in Table 4, forty-nine of our large owners are institutions. In nine of these cases, it is the company owning its own shares-particularly among banks and insurance companies, which sought to make markets in their own shares. ${ }^{50}$ Eleven of the institutional large owners are banks; however, this does not provide partial absolution from the charge that banks failed British industry, since they were all large shareholders in foreign companies. A further eleven of the institutional large shareholders were investment trusts. Notably, in ten of the eleven instances where an investment trust is a large shareholder, the shareholding is in a foreign company, and no investment trust was a large owner prior to $1891 .^{51}$ In seventeen cases, another company is the large shareholder and that company usually operates in the same industry.

The overall finding from our analysis of the socio-occupational backgrounds of large shareholders is that many large shareholders were rentiers or passive investors who were not involved in governance. Notably, manufacturers and merchants who were large shareholders appear to have played a more active role in firm governance than did other socio-occupational groups, and many of them appear to have been large shareholders in family firms. 
Having established the socio-occupational background of large shareholders, we now move on to another question: where were large shareholders from? We perform this analysis for two reasons. First, we want to see if large London capitalists, who were more likely to be rentiers than other capitalists were, invested in foreign or domestic companies. Second, given that many large shareholders did not play a governance role, we want to see how close large shareholders lived to the companies in which they invested.

Five geographic areas dominate: London (34.6 percent of large shareholders), Lancashire (12.2 percent), Yorkshire (7.0 percent), Scotland (13.6 percent), and overseas (5.1 percent). Notably, the first three areas were those that had provided the bulk of capital during the development of the railways in the $1840 \mathrm{~s} .{ }^{52}$ London provided the largest pool of large shareholders, but its share of large investors (34.6 percent) was somewhat below its share of companies headquartered there (45.6 percent). Lancashire provided the second largest pool of large shareholders, which mirrored the share of companies headquartered there. Notably, while London provided 51.6 percent of all large shareholders in foreign companies, Lancashire and Yorkshire provided only 5.9 percent. This suggests that it was London wealth rather than Lancashire or Yorkshire wealth that financed foreign companies. ${ }^{53}$

The importance of Scotland as a source of large shareholders arises purely because we have Scottish companies in our sample. ${ }^{54}$ Only 15 of the 157 large investors from Scotland were large shareholders in a non-Scottish company, and only 26 large shareholders in 162 Scottish-registered companies were from outside Scotland, with 10 of the 26 being from overseas and 16 from England. This suggests both that capital markets were geographically segmented in the Victorian era and that large shareholders lived close to the companies they invested in. Notably, nearly 12 percent of all large shareholders in foreign companies came from Scotland. This can largely be attributed to the large number of freestanding companies that were incorporated in Scotland. ${ }^{55}$ In a similar vein, many overseas companies registered in London, which may explain the high share of London addresses in the number of large shareholders in overseas companies. 
Large investors from overseas constituted 5.1 percent of our sample of large shareholders but contributed 10.9 percent of the capital provided by large owners. These foreign large shareholders were usually investing in British-registered companies that had operations in the country where they were domiciled and not in companies with operations in the United Kingdom. In total, 16.1 percent of large shareholders in foreign companies were from overseas.

Having established that the geographic spread of large investors largely mirrored the geographic spread of company headquarters, we now move on to this question: how close to their company's headquarters did large shareholders live? In the Victorian era, a large shareholder's ability to influence the firm or monitor its directors may have been largely determined by how close they lived to their company's headquarters. Notably, even companies we describe as foreign had their headquarters in the United Kingdom. We have head office details for 771 large shareholders, and we find that 520 of them lived in the same county as the company in which they were the large shareholder. This proximity may have been partially driven by the provincial nature of the British capital market at the time. Such a capital market gave large investors access to information as well as possible influence over the company.

\section{The Wealth of Large Shareholders}

In this section, we examine the wealth of our sample of large shareholders. We do so for several reasons. First, it may tell us whether the companies they invested in were family companies to which they had committed large proportions of their wealth. Second, it will help us to understand whether large capitalists in this era were members of the superrich or from the moderately wealthy middle class.

To estimate the wealth of a large shareholder, we use their terminal wealth as recorded in probate records. Several caveats must be borne in mind when using probate records as an estimate of a person's wealth. The first thing to bear in mind is that probate records may underestimate a decedent's true wealth. ${ }^{56}$ The second is that probate records may not be representative of a person's wealth when they were a large shareholdersomeone could have made or lost a fortune between the time they were a large 
shareholder and the time of their death. We therefore run a set of robustness checks on our probated wealth data by looking at the subsample of individuals who died within two and ten years of an ownership census in which they were identified as a large shareholder.

We use Ancestry.com to trace the probated effects of large investors as reported in will calendars. Unfortunately, most Scottish wills were sealed, with the result that no effects are reported. In order to ensure that the probate records were actually those of large shareholders, we required that the address, occupation, and name (plus initials, if any) as recorded in probate records matched those recorded in the ownership returns. This rigorous methodology and the absence of effects in the Scottish probate records means that we have probated wealth for only one half of our large shareholders.

Fifty-two of our large shareholders have probated wealth that was substantially below the paid-up value of their shareholding; all had low wealth and died a median of nineteen and a half years after the ownership census date in which they are recorded as large shareholders. These large shareholders obviously had lost a lot of money before they died. ${ }^{57}$ Since these 52 individuals overly influence the ratio of the value of a shareholding to probated wealth, we omit them from our analysis in Table 5. As a result, we have 529 large shareholders in our sample. For the sake of comparison, all probate values in Table 5 are converted into 1900 values using Jim O'Donoghue, Louise Goulding, and Grahame Allen's composite price index. ${ }^{58}$

\section{[INSERT TABLE 5]}

As can be seen in Table 5, the large shareholders in our sample of Victorian companies had a mean (median) wealth of $£ 342,700$ ( $£ 97,900$ ). To provide some context, Peter Lindert estimates that in 1875 , the average estate of merchants was $£ 11,804$, that of gentlemen and the nobility was $£ 9,855$, and that of professionals only $£ 1,201 .{ }^{59}$ To put this into further perspective, W. D. Rubinstein, in his study of probate records, finds that there were only 158 millionaires and 383 half-millionaires in the United Kingdom in the period from 1880 to $1914 .^{60}$ Tom Nicholas, in his study of the 790 British businessmen listed in the Dictionary of Business Biography, finds that the median probate of 
prominent businessmen was $£ 154,471$ for those born between 1800 and 1840 and $£ 134,275$ for those born between 1840 and 1880 . $^{61}$

The bottom two rows of Table 5 reveal that the median wealth of those who died within ten and two years of being recorded as a shareholder in an ownership return is only slightly lower than that of the overall sample. This suggests that large shareholders were typically very wealthy when they were large owners and did not necessarily become wealthy as a result of being a large shareholder.

Across the overall sample, we see in Table 5 that the mean and median ratio of the par value of a large investor's shareholding to their probated wealth was 14.1 and 6.3 percent, respectively. These figures increase slightly for those shareholders who died within ten and two years of being recorded as a large shareholder. In other words, the average large shareholder invested a considerable proportion of their income in the companies where they were a large owner. Taken with the findings above, the significant proportion of overall wealth invested in companies is surprising given the low probability that large shareholders were directors or exercised control. Notably, the correlation coefficient between the proportion of wealth invested in a company and being a director is low, being only 0.07 .

In terms of industry, the least wealthy large shareholders were in the spinning and weaving, steamship, and wagon industries (Table 5). However, large investors in these industries usually had more of their wealth tied up in the company than did those in other industries, which may indicate family ownership or heightened confidence in the company because it was a conversion and therefore had a track record. Notably, large shareholders in these industries were more likely to be directors than large shareholders in other industries were (Table 4). The lowest ratios of par value to probated wealth were in finance, insurance, and gas, light, and waterworks. These industries attracted wealthy investors and were much less likely than other industries to be family concerns.

There is no statistical difference between the mean (and median) of the wealth of large owners who invested in foreign companies and that of those who invested in domestic companies. Thus, there is no evidence to indicate that the superwealthy were large shareholders in foreign companies, leaving the moderately wealthy to be large shareholders in domestic companies. 
In terms of socio-occupational background, large shareholders who were women and those who were members of the legal profession had the lowest wealth, while politicians and members of the nobility were the wealthiest groups of large investors. Thus, the members of the governing elite who were large shareholders were also very wealthy individuals. Notably, manufacturers had the highest ratio of par value to probated wealth among all socio-occupational classes, which is consistent with the results above, suggesting a greater likelihood that manufacturing companies were family-controlled (Table 4).

Table 6 contains details of the large shareholders in our sample who were millionaires in terms of 1900 prices. Five things are worth highlighting. First, apart from Christian Allhusen and George Muntz, these millionaires were not large shareholders in companies they had founded nor were part of the founding family, suggesting that the wealthiest large shareholders were merely investors. Notably, only nine of the twentythree millionaires were directors in the companies they had invested in. Second, in terms of socio-occupational background, twelve millionaires came from industry and manufacturing, nine from finance, one from the landed gentry, and one was a journalist. This supports Nicholas's analysis of wealth holding, which suggests that even among the superwealthy there was a heterogeneous pattern of wealth holding, while there is little evidence to support Rubinstein's hypothesis that wealth was concentrated in the hands of individuals active in finance and commercial pursuits. ${ }^{62}$ Third, sixteen of these twentythree millionaires were based in London, which lends some support to Rubinstein's hypothesis that wealth in this era was concentrated in London rather than the provinces. ${ }^{63}$ Fourth, these millionaires did not commit a large proportion of their wealth to these companies, with Christian Allhusen and George Muntz having the highest percentage of their wealth tied up in their companies - but even these are relatively low percentages. Fifth, eleven of these twenty-three millionaires were large shareholders in overseas companies rather than British companies.

[INSERT TABLE 6] 


\section{Conclusion}

Our findings suggest that the majority of large shareholders in Victorian Britain did not own large portions of the voting rights in the companies they invested in. Furthermore, the majority of large investors were not directors and neither were their family members. We also observe substantial churn among large shareholders. Taken together, these findings imply that the majority of public companies in the second half of the nineteenth century cannot be characterized as being family companies and that large shareholders are better viewed as wealthy capitalists rather than entrepreneurs. There are some exceptions to these findings: large shareholders in breweries, iron and steel companies, spinning and weaving companies, and manufacturing companies usually had substantial voting rights and were much more likely than those in other industries to be directors. There was also less churn of large shareholders in these sectors. In addition, it was much more likely that companies in these sectors were family firms. We also see that companies established during and after the 1890s were more likely to be family firms than those set up earlier, with large shareholders playing an important governance role.

In terms of the identity of the capitalists who backed companies in the second half of the nineteenth century, we find that the majority of them can be categorized as gentlemen, merchants, or manufacturers. Thus, the main backers of Victorian public companies were primarily wealthy rentiers or businessmen. About one third of large shareholders came from London, but a considerable proportion came from the industrial heartland of Lancashire as well as Yorkshire. Large shareholders in overseas companies were more likely to be gentleman capitalists from London, while manufacturers and Lancashire-based individuals were typically large investors in domestic companies.

Many of the large shareholders in our sample were among some of the wealthiest individuals in the nineteenth and early twentieth centuries. Thus, the superwealthy from across the nation played an important part in financing British public companies during this important phase in the development of the public corporation and capital market, and they did so without necessarily having much control over the companies in which they invested. Furthermore, we find no evidence of a financial dichotomy, in that those who had become very wealthy because of the industrial revolution and those who had become 
very wealthy through commercial and financial business both contributed to this expansion of British business and the British capital market in the Victorian era.

The main finding of this article revises the prevalent perception that British public companies in the Victorian era had large owners and were dominated by families. Up until recently, the standard view has been that ownership separated from control in the United Kingdom at some stage in the second half of the twentieth century. However, the reality appears to be more nuanced: it appears that in the history of the U.K. corporation over the past two centuries, ownership was initially separated from control; then, around the turn of the twentieth century, ownership began to become more concentrated; and then, at some stage after 1950, ownership began to separate from control once again. These changes in the nature of corporate ownership in the United Kingdom and their long-term impact on the capital market are something that business historians should investigate in future research.

GRAEME G. ACHESON is professor of finance at Stirling University. His recent research, focused on limited liability, banking, and financial history, has been published in Business History, Economic History Review, Journal of Economic History, and Explorations in Economic History.

GARETH CAMPBELL is lecturer in finance at Queen's University, Belfast. His recent research, which focuses on asset pricing bubbles and financial history, has been published in Business History Review, Economic History Review, and Explorations in Economic History. He was awarded the Economic History Society New Researcher Prize in 2009 .

JOHN D. TURNER is professor of finance and financial history at Queen's University, Belfast, director of the Queen's University Centre for Economic History, and dean of the Queen's Management School. He has been a Houblon-Norman Fellow at the Bank of England and the Alfred D. Chandler Jr. International Visiting Scholar at Harvard 
Business School. He recently published a book with Cambridge University Press entitled Banking in Crisis: The Rise and Fall of British Banking Stability, 1800 to the Present.

Thanks to the Leverhulme Trust (Grant no. F/00203/Z) for financial support. Thanks also to Nadia Vanteeva for her input into this project. Turner also wishes to thank Geoff Jones, Walter Friedman, and Harvard Business School for their hospitality at the outset of this project. Thanks to the archivists at the National Archives at Kew, the National Archives of Scotland, and the Guildhall Library for all their assistance.

${ }^{1}$ For an excellent summary and critique of this view, see Leslie Hannah, "The Divorce of Ownership from Control from 1900: Recalibrating Imagined Global Historical Trends," Business History 49 no.4 (2007): 404-38.

${ }^{2}$ The literature on when ownership separated from control in the U.K. posits a wide variety of possibilities; see P. S. Florence, Ownership, Control and Success of Large Corporations: An Analysis of English Industrial Structure and Policy, 1936-1951 (London, 1961); Steve Nyman and Aubrey Silberston, “The Ownership and Control of Industry," Oxford Economic Papers 30 no.1 (1978): 74-101; John Scott, "Corporate Control and Corporate Rule: Britain in an International Perspective," British Journal of Sociology 41 no.3 (1990): 351-73; Dennis Leech and John Leahy, "Ownership Structure, Control Type Classifications and the Performance of Large British Companies," Economic Journal 101 no. 409 (1991): 1418-37; Brian R. Cheffins, Corporate Ownership and Control: British Business Transformed (Oxford, 2008); John C. Coffee, "The Rise of Dispersed Ownership: The Roles of Law and the State in the Separation of Ownership and Control," Yale Law Journal 111 no.1 (2001): 1-82; Mark J. Roe, "Political Preconditions to Separating Ownership from Corporate Control," Stanford Law Review 53 no.3 (2000): 539-606; Julian Franks, Colin Mayer, and Stefano Rossi, “Ownership: Evolution and Regulation,” Review of Financial Studies 22 no.10 (2009): 4009-56; Hannah, "Divorce of Ownership"; and James ForemanPeck and Leslie Hannah, "Extreme Divorce: The Managerial Revolution in U.K. Companies before 1914," Economic History Review 65 no.4 (2012): 1217-38. In particular, Hannah, "Divorce of Ownership," and Foreman-Peck and Hannah, "Extreme Divorce," argue that ownership had separated from control by 1900. There is also debate with respect to the United States; see Adolf Berle and Gardiner Means, The Modern Corporation and Private Property (New York, 1932); Brian R. Cheffins and Steve Bank, "Is Berle and Means Really a Myth?” Business History Review 83 (Autumn 2009): 443-74; Clifford G. Holderness, “The Myth of Diffuse Ownership in the United States," Review of Financial Studies 22 no.4 (2009): 1377-408; and Kenneth Lipartito and Yumiko Morii, "Rethinking the Separation of Ownership from Management in American History," Seattle University Law Review 33 no.4 (2010): 1025-63. Eric Hilt finds diffuse ownership in New York in the early part of the nineteenth century; see Hilt, "When Did Ownership 
Separate from Control? Corporate Governance in the Early Nineteenth Century," Journal of Economic History 68 no.3 (2008): 645-85.

${ }^{3}$ On the liberalization of incorporation law in the U.K. and the emergence of large companies, see Philip L. Cottrell, Industrial Finance, 1830-1914 (London, 1980); James B. Jefferys, Business Organisation in Great Britain, 1856-1914 (New York, 1977); Peter L. Payne, "The Emergence of the Large-Scale Company in Great Britain, 1870-1914," Economic History Review 20 no.3 (1967): 519-42; and James Taylor, Creating Capitalism: Joint-Stock Enterprise in British Politics and Culture, 1800-1870 (London, 2006), 135-75.

${ }^{4}$ Graeme G. Acheson, Gareth Campbell, John D. Turner, and Nadia Vanteeva, "Corporate Ownership and Control in Victorian Britain," Economic History Review 68, no. 3 (2015): 911-936

${ }^{5}$ The 1855 Limited Liability Act (18 \& 19 Vict., c. 113) was repealed, but reenacted in 1856 (19 \& 20 Vict., c. 47). The 1856 act granted free incorporation with limited liability. A consolidation of existing company legislation occurred with the passage of the 1862 Companies Act ( 25 \& 26 Vict., c. 89).

${ }^{6}$ Ranald C. Michie, The London Stock Exchange (Oxford, 1999), 88-89; Richard S. Grossman, "New Indices of British Equity Prices, 1870-1913," Journal of Economic History 62 no. 1 (2002): 121-46; Janette Rutterford, David R. Green, Josephine Maltby, and Alastair Owens, "Who Comprised the Nation of Shareholders? Gender and Investment in Great Britain, c.1870-1935," Economic History Review 64 no.1 (2011): 157-87. On this role of large shareholders, see Andrei Shleifer and Robert W. Vishny, "Large Shareholders and Corporate Control," Journal of Political Economy 94 no.3 (1986): 461-88; Andrei Shleifer and Robert W. Vishny, “A Survey of Corporate Governance,” Journal of Finance 52 no.2 (1997): 737-83; Rafael La Porta, Florencio Lopez-de-Silanes, and Andrei Shleifer, "Corporate Ownership around the World," Journal of Finance 54 no.2 (1999): 471-517; and Bo Becker, Henrik Cronqvist, and Rüdiger Fahlenbrach, "Estimating the Effects of Large Shareholders Using a Geographic Instrument," Journal of Financial and Quantitative Analysis 46 no.4 (2011): 907-42.

${ }^{7}$ Colin Mayer, Firm Commitment: Why the Corporation is Failing Us and How to Restore Trust in It (Oxford, 2013).

${ }^{8}$ Hilt, "When Did Ownership Separate"; Aldo Musacchio, Experiments in Financial Democracy: Corporate Governance and Financial Development in Brazil, 1882-1950 (Cambridge, U.K., 2009), 10526.

${ }^{9}$ Alfred D. Chandler Jr., Scale and Scope: The Dynamics of Industrial Capitalism (Cambridge, Mass., 1990), 240.

${ }^{10}$ Bernard Elbaum and William Lazonick, "The Decline of the British Economy: An Institutional Perspective," Journal of Economic History 44 no.2 (1984): 567-83. For an opposing view, see D. N. McCloskey, “Did Victorian Britain Fail?" Economic History Review 23 no.3 (1970): 446-59, and D. N. McCloskey and L. Sandberg, "From Damnation to Redemption: Judgments on the Late Victorian Entrepreneur," Explorations in Economic History 9 no.1 (1971): 89-108. 
11 Ranald C. Michie, Guilty Money: The City of London in Victorian and Edwardian Culture, 1815-1914 (London, 2009); B. L. Anderson and Philip L. Cottrell, “Another Victorian Capital Market: A Study of Banking and Bank Investors on Merseyside," Economic History Review 28 no.4 (1975): 600-615; Lucy A. Newton and Philip L. Cottrell, "Female Investors in the First English and Welsh Commercial Joint-Stock Banks," Accounting, Business and Financial History 16 no.2 (2006): 315-40; John D. Turner, "Wider Share Ownership? Investors in English Bank Shares in the Nineteenth Century," Economic History Review 62 no. s1 (2009): 167-92; Graeme G. Acheson and John D. Turner, "Investor Behavior in a Nascent Capital Market: Scottish Bank Shareholders in the Nineteenth Century," Economic History Review 64 no. 1 (2011): 188-213; John F. Wilson, Lighting the Town: A Study of Management in the North West Gas Industry, 1805-1880 (London, 1991); S. A. Broadbridge, "The Sources of Railway Share Capital," in Railways in the Victorian Economy: Studies in Finance and Economic Growth, ed. M. C. Reed (New York, 1968), 184-211; Gareth Campbell and John D. Turner, "Dispelling the Myth of the Naive Investor during the Railway 'Mania' Boom in Britain, 1845-46,' Business History Review 86 (Spring 2012): 3-41; Harold Pollins, "The Finances of the Liverpool and Manchester Railway," Economic History Review 5 no. 1 (1952): 90-97; M. C. Reed, "Railways and the Growth of the Capital Market," in Railways in the Victorian Economy: Studies in Finance and Economic Growth, ed. M. C. Reed (New York, 1968), 162-83. M. C. Reed, Investment in Railways in Britain 1820-1844: A Study in the Development of the Capital Market (Oxford, 1975); Janette Rutterford and Josephine Maltby, “The Nesting Instinct: Women and Investment Risk in a Historical Context," Accounting History 12 no. 3 (2007): 305-27; Janette Rutterford and Josephine Maltby, "The Widow, the Clergyman, and the Reckless: Women Investors in England, 18301914," Feminist Economics 12 no. 1-2 (2006): 111-38; Rutterford et al., "Who Comprised the Nation."

${ }^{12}$ For a case study of one large investor in the Victorian era, see Ranald C. Michie, "Income, Expenditure, and Investment of a Victorian Millionaire: Lord Overstone, 1823-83," Historical Research 58 no. 137 (1985): 59-77.

13 This view was put forward in the Macmillan Report (Report of Committee on Finance and Industry, House of Commons, 1931). See, also, Michael Edelstein, Overseas Investment in the Age of High Imperialism: The United Kingdom, 1850-1914 (New York, 1982); Sidney Pollard, “Capital Exports, 18701914: Harmful or Beneficial?” Economic History Review 38 no. 4 (1985): 489-514; William P. Kennedy, Industrial Structure, Capital Markets, and the Origins of British Economic Decline (Cambridge, U.K., 1987); Kevin H. O’Rourke and Jeffery G. Williamson, Globalization and History: The Evolution of a Nineteenth-Century Atlantic Economy (Cambridge, U.K., 1999), chap. 12; William N. Goetzmann and Andrey D. Ukhov, "British Investment Overseas, 1870-1913: A Modern Portfolio Theory Approach,” Review of Finance 10 no. 2 (2006): 261-300; Benjamin R. Chabot and Christopher J. Kurz, “That's Where the Money Was: Foreign Bias and English Investment Abroad, 1866-1907," Economic Journal 120 no. 547 (2010): 1056-79; Richard S. Grossman, "Bloody Foreigners! Overseas Equity on the London Stock Exchange, 1869-1928,” Economic History Review vol. $\quad$ 68, no. 2 (2015): 471-521

1419 \& 20 Vict., c. 47 ; 25 \& 26 Vict. c. 89. 
${ }^{15}$ The Course of the Exchange reported prices of securities traded on the London market whereas the Investor's Monthly Manual also reported prices of securities traded the provincial markets.

${ }^{16}$ In total, these two price lists provided a sample of 2,765 public companies; after searching the BT2 and BT31 catalogues, we uncovered ownership records for around 900 of these. However, many company files contained no ownership returns and those that did had been extensively weeded to reduce their bulk. Thus, our strategy was to collect all surviving ownership returns for 1865, 1870, 1883, 1890, and 1900 , or one year either side of these sample years if the return existed. If they were available, 1880 or 1881 were collected in those cases where a company had no returns for 1882-1884. In addition, we collected all returns from the 1850s. If a company had ownership returns that fell outside the selected sample years, we collected a return for each decade between 1860 and 1900, where available. We photographed 999 ownership returns (Form E), which were then inputted manually and verified by dataentry services. In total, after removing firm-years with missing and unintelligible data, we had ownership returns for 890 firm-years.

${ }^{17}$ Grossman, "New Indices."

18 Graeme G. Acheson, Charles R. Hickson, John D. Turner, and Qing Ye, "Rule Britannia! British Stock Market Returns, 1825-1870,” Journal of Economic History 69 no. 4 (2009): 1107-37; Grossman, "New Indices," 130.

${ }^{19}$ Notably, about 29 percent of companies had their shares traded on more than one stock market.

${ }^{20}$ On the development of these provincial stock exchanges, see William A. Thomas, The Provincial Stock Exchanges (London, 1973).

${ }^{21}$ Brian R. Cheffins, David Chambers, and Dmitri K. Koustas, "Ownership Dispersion and the London Stock Exchange's 'Two-Thirds Rule': An Empirical Test,” Business History 55 no. 4 (2013): 67093; Mara Faccio and Larry H. P. Lang, "The Ultimate Ownership of Western European Corporations," Journal of Financial Economics 65 no. 3 (2002): 365-95; La Porta, Lopez-de-Silanes, and Shleifer, "Corporate Ownership."

22 Debentures were corporate bonds, and it was only in the latter part of the 1880s that they became common amongst non-railway companies (Christopher Coyle and John D. Turner, "Law, Politics, and Financial Development: The Great Reversal of the U.K. Corporate Debt Market," Journal of Economic History 73 no. 3 [2013]: 809-45).

${ }^{23}$ La Porta, Lopez-de-Silanes, and Shleifer, "Corporate Ownership."

${ }^{24}$ For example, the voting scheme of the iron, coal, and steel producer Bolchow, Vaughan and Company granted one vote for every share held up to two hundred and one vote for every five shares held beyond two hundred (see company's articles of association). The voting scheme of Muntz's Metal Company was as follows: one vote for every ten shares up to a maximum of ten votes (see company's articles of association). The voting scheme of the Wakefield and Barnsley Union Bank was as follows: 5 to 20 shares $=$ one vote; 21 to 50 shares $=$ two votes; 51 to 100 shares $=$ three votes; 101 to 200 shares $=$ six 
votes; 201 to 300 shares = eight votes; above 301 shares = ten votes (Stock Exchange Official Intelligence, 1890).

${ }^{25}$ Jefferys, Business Organisation, 268. In addition to this capital-raising motivation, partnerships were also converted to help founding entrepreneurs fully or partially cash out and to diversify the ownership; see John Armstrong, "The Rise and Fall of the Company Promoter and the Financing of British Industry," in Capitalism in a Mature Economy: Financial Institutions, Capital Exports, and British Industry, 1870-1939, ed. Jean Jacques Van Helten and Youssef Cassis (Aldershot, U.K., 1990), 118. These motives were certainly at play in some brewing conversions; see Terry R. Gourvish and Richard G. Wilson, The British Brewing Industry, 1830-1980 (Cambridge, U.K., 1994), 257, and Katherine Watson, "Banks and Industrial Finance: The Experience of Brewers, 1880-1913," Economic History Review 49 no. 1 (1996): 58-81.

${ }^{26}$ Cottrell, Industrial Finance, 168; Gourvish and Wilson, British Brewing Industry, 257; Payne, "Large-Scale Company," 531; Watson, "Banks and Industrial Finance."

${ }^{27}$ For the incorporation of iron, coal, and steel companies, see Jefferys, Business Organisation, 74; Lucy Newton, "The Finance of Manufacturing Industry in the Sheffield Area c. 1850-1885," (PhD diss., University of Leicester, 1993), 291-341; Katherine Watson, “The New Issue Market as a Source of Finance for the U.K. Brewing and Iron and Steel Industries, 1870-1913," in The Evolution of Financial Institutions and Markets in Twentieth-Century Europe, ed. Youssef Cassis, Gerald D. Feldman, and Ulf Olsson (Aldershot, U.K., 1995), 211-50.

${ }^{28}$ Jefferys, Business Organisation, 84-90; Douglas A. Farnie, The English Cotton Industry and the World Market, 1815-1896 (Oxford, 1979), 209-27.

${ }^{29}$ Graeme G. Acheson, Charles R. Hickson, and John D. Turner, "Does Limited Liability Matter? Evidence from Nineteenth-Century British Banking," Review of Law and Economics 6 no.2 (2011): 24773; Hannah, "Divorce of Ownership."

${ }^{30}$ John D. Turner, Banking in Crisis: The Rise and Fall of British Banking Stability, 1800 to the Present (Cambridge, U.K., 2014), 118. Another possible reason is that the existence of a large shareholder might discourage others from investing since such owners could use their dominance to expropriate minority shareholders in a sector characterized by high levels of information asymmetry (Acheson, Hickson, and Turner, "Does Limited Liability Matter?" 259). Other types of companies may have had these types of restrictions on votes of large shareholder because of (a) the need to develop stakeholder trust (particularly in the case of public utilities), (b) tradition, or (c) political influence. However, such restrictions became less common as the nineteenth century progressed. See Mark Freeman, Robin Pearson, and James Taylor, Shareholder Democracies? Corporate Governance in Britain and Ireland before 1850 (Chicago, 2012), 143-76.

${ }^{31}$ A caveat needs to be placed on this method because commonly occurring surnames could result in an overidentification of family firms, whereas not taking into account family links via marriage could result in underidentification. 
${ }^{32}$ Cheffins, Corporate Ownership, 181-82.

${ }^{33}$ Acheson et al., "Corporate Ownership."

${ }^{34}$ Jefferys, Business Organisation, 268.

${ }^{35}$ Gareth Campbell and John D. Turner, "Substitutes for Legal Protection: Corporate Governance and Dividends in Victorian Britain,” Economic History Review 64 no. 2 (2011): 571-97.

${ }^{36}$ One caveat is that some wealthy individuals may have had both a London and a county address, and we cannot be sure which is reported in the shareholder returns. However, given that many of our companies were traded on provincial stock exchanges, this may be less of a problem because individuals with both a London and county address were much less likely to invest in such companies.

${ }^{37}$ For example, one individual who was a large shareholder in four different companies was Charles Morrison, who, although described as a gentleman in the four of our shareholder returns, was in reality a behind-the-scenes individual financier with a massive fortune, which made him one of the wealthiest men in Britain at the time of his death in 1909. See W. D. Rubinstein, "Morrison, Charles (1817-1909)," Oxford Dictionary of National Biography (Oxford, 2004); and Charles A. Jones, "Great Capitalists and the Direction of British Overseas Investment in the Late Nineteenth Century: The Case of Argentina," Business History 22 no. 2 (1980): 152-69.

${ }^{38}$ However, even this has to be treated with caution since some businessmen may have acquired land to enhance their social status. On land ownership by businessmen, see Tom Nicholas, "Businessmen and Land Ownership in the Late Nineteenth Century," Economic History Review 52 no. 1 (1999): 27-44.

${ }^{39}$ We define nobility as peers and children of peers (i.e., those having the title Honorable in front of their names).

${ }^{40}$ Hugh Brigstocke, "Lindsay, Alexander William Crawford, twenty-fifth earl of Crawford and eighth earl of Balcarres (1812-1880)," Oxford Dictionary of National Biography (Oxford, 2004).

${ }^{41}$ David R. Green and Alasdair Owens, "Gentlewomanly Capitalism? Spinsters, Widows, and Wealth Holding in England and Wales," Economic History Review 56 no. 3 (2003): 510-36; Newton and Cottrell, "Female Investors"; Rutterford and Maltby, "The Nesting Instinct" and "Women Investors in England"; Rutterford et al., "Who Comprised the Nation."

${ }^{42}$ Twenty were widowed, seven were married, and seven were spinsters. Married women could not own property in their own name prior to the Married Women's Property Act of 1882 (45 \& 46 Vict., c. 75).

${ }^{43}$ On this, see Rutterford and Maltby, "The Nesting Instinct" and "Women Investors in England," and Rutterford et al., "Who Comprised the Nation."

${ }^{44}$ On this debate, see Michael H. Best and Jane Humphries, "The City and Industrial Decline," in The Decline of the British Economy, ed. Bernard Elbaum and William Lazonick (Oxford, 1986), 223-39; Forrest Capie and Terence C. Mills, "British Bank Conservatism in the Late Nineteenth Century," Explorations in Economic History 32 no. 3 (1995): 409-20; Richard S. Grossman, "Rearranging Deck Chairs on the Titanic: English Banking Concentration and Efficiency, 1870-1914," European Review of 
Economic History 3 no. 3 (1999): 323-49; Forrest Capie and Michael Collins, "Industrial Lending by English Commercial Banks, 1860s-1914: Why Did Banks Refuse Loans?” Business History 38 no. 1 (1996): 26-44; Forrest Capie and Michael Collins, Have the Banks Failed British Industry? (London, 1992); Caroline Fohlin, "The Balancing Act of German Universal Banks and English Deposit Banks, 1880-1913," Business History 43 no. 1 (2001): 1-24; Michael Collins and Mae Baker, Commercial Banks and Industrial Finance in England and Wales, 1860-1913 (Oxford, 2003).

${ }^{45}$ On the role of politicians as directors in late Victorian companies, see Fabio Braggion and Lyndon Moore, "The Economic Benefits of Political Connections in Late Victorian Britain," Journal of Economic History 73 no. 1 (2013): 142-76.

${ }^{46}$ Kimberley Morse John, "Quilter, Sir William Cuthbert, first baronet (1841-1911)," Oxford Dictionary of National Biography (Oxford, 2004).

${ }^{47}$ On the relationship between banks and industry in this era, see Lucy A. Newton, "The Birth of Joint-Stock Banking: England and New England Compared," Business History Review 84 (Spring 2010): 27-52, and Lucy A. Newton, "Regional Bank-Industry Relations during the Mid-Nineteenth Century: Links between Bankers and Manufacturing in Sheffield, c. 1850 to c. 1885," Business History 38 no. 3 (1996): 64-83.

${ }^{48}$ See Geoffrey Tweedale, "Bessemer, Sir Henry (1813-1898)," Oxford Dictionary of National Biography (Oxford, 2004).

${ }^{49}$ His shareholding in this company is consistent with the belief that he had substantial assets abroad. See David Brooke, "Brassey, Thomas (1805-1870)," Oxford Dictionary of National Biography (Oxford, 2004).

${ }^{50}$ Graeme G. Acheson and John D. Turner, "The Secondary Market for Bank Shares in Nineteenth-Century Britain,” Financial History Review 15 no. 2 (2008): 123-51.

${ }^{51}$ Investment trusts, starting with Foreign and Colonial in 1868, invested mainly in foreign and colonial debentures rather than equity.

52 Broadbridge, "Sources of Railway Share Capital," 186; Campbell and Turner, "Dispelling the Myth," 15-16; Reed, Investment in Railways, 193-95.

${ }^{53}$ This is consistent with P. J. Cain and A. G. Hopkins, "Gentlemanly Capitalism and British Expansion Overseas II: New Imperialism, 1850-1945," Economic History Review 40 no. 1 (1987): 1-26.

${ }^{54}$ For a detailed account of the early Scottish limited companies, see Peter L. Payne, The Early Scottish Limited Companies, 1856-1895 (Edinburgh, 1980).

${ }^{55}$ On freestanding companies, see Mira Wilkins, "The Free-Standing Company, 1870-1914: An Important Type of British Foreign Direct Investment," Economic History Review 41 no. 2 (1988): 259-82.

${ }^{56}$ They do so for at least three reasons. First, prior to death, decedents may have made inter vivos gifts to their families or may have attempted to reduce their wealth to avoid death duties. Second, probate is not required in cases where property is jointly held, as the property passes automatically to the surviving joint owner, usually a spouse. Third, prior to 1898 , the wealth reported in probate records includes only 
unsettled personalty (i.e., property other than land). From 1898 it included unsettled realty (e.g., land) and from 1926 it included settled realty. [AU: Please check that "i.e." was meant, not "e.g."]

${ }^{57}$ Notably, according to the Register of Defunct Companies, seventeen of the fifty were large shareholders in companies that were liquidated before they had died.

${ }^{58}$ Jim O’Donoghue, Louise Goulding, and Grahame Allen, “Composite Price Index, 1750-2003,” Economic Trends 604 (2004): 38-46.

${ }^{59}$ Peter H. Lindert, “Unequal English Wealth since 1670," Journal of Political Economy 94 no. 6 (1986): 1127-62.

${ }^{60}$ W. D. Rubinstein, "The Victorian Middle Classes: Wealth, Occupation, and Geography," Economic History Review 30 no.4 (1977): 602-23.

${ }^{61}$ Tom Nicholas, "Wealth Making in Nineteenth- and Early Twentieth-Century Britain: Industry versus Commerce and Finance," Business History 41 no. 1 (1999): 16-36.

${ }^{62}$ Nicholas, "Wealth Making”; Rubinstein, "The Victorian Middle Classes."

${ }^{63}$ Rubinstein, "The Victorian Middle Classes." 
Table 1

Industry Breakdown of Sample

\begin{tabular}{|c|c|c|c|c|c|c|c|}
\hline & $1850 \mathrm{~s}$ & $1860 \mathrm{~s}$ & $1870 s$ & $1880 \mathrm{~s}$ & $1890 s$ & $1900 s$ & Total \\
\hline Banks & 1 & 30 & 25 & 46 & 26 & 14 & 142 \\
\hline Breweries & 0 & 3 & 4 & 7 & 15 & 8 & 37 \\
\hline Commercial and Industrial & 4 & 54 & 32 & 62 & 64 & 33 & 249 \\
\hline Docks & 0 & 0 & 0 & 2 & 0 & 1 & 3 \\
\hline Finance & 2 & 11 & 7 & 6 & 3 & 1 & 30 \\
\hline Gas and Light & 4 & 9 & 4 & 9 & 9 & 6 & 41 \\
\hline Insurance & 1 & 8 & 10 & 14 & 12 & 5 & 50 \\
\hline Iron, Coal and Steel & 0 & 5 & 9 & 25 & 18 & 10 & 67 \\
\hline Mines & 2 & 11 & 5 & 11 & 11 & 8 & 48 \\
\hline Mortgage and Land & 0 & 3 & 3 & 34 & 23 & 15 & 78 \\
\hline Spinning and Weaving & 0 & 3 & 1 & 17 & 12 & 2 & 35 \\
\hline Steamships & 0 & 8 & 4 & 12 & 5 & 8 & 37 \\
\hline Tea and Coffee & 0 & 8 & 3 & 2 & 3 & 0 & 16 \\
\hline Telegraph & 1 & 1 & 5 & 7 & 3 & 2 & 19 \\
\hline Tramways & 0 & 0 & 2 & 9 & 9 & 4 & 24 \\
\hline Wagon & 0 & 2 & 1 & 4 & 5 & 2 & 14 \\
\hline Foreign & 4 & 45 & 28 & 72 & 68 & 42 & 259 \\
\hline Domestic & 11 & 111 & 87 & 195 & 150 & 77 & 631 \\
\hline Total & 15 & 156 & 115 & 267 & 218 & 119 & 890 \\
\hline
\end{tabular}

Source: See text. Companies Registration Office files at the National Archives at Kew (BT31 series) and the National Archives of Scotland (BT2 series).

Note: The industry classification used above is that used by contemporary stock exchange manuals such as the Stock Exchange Official Intelligence. 
Table 2

Percentage of Capital / Votes Owned by Largest Shareholder

\begin{tabular}{|c|c|c|c|c|c|c|}
\hline & \multicolumn{3}{|c|}{ Capital } & \multicolumn{3}{|c|}{ Votes } \\
\hline & Average & Median & Stdev & Average & Median & Stdev \\
\hline \multicolumn{7}{|l|}{ PANEL A: INDUSTRY } \\
\hline Banks & 5.4 & 4.0 & 4.4 & 3.7 & 2.0 & 4.4 \\
\hline Breweries & 17.0 & 13.7 & 12.2 & 16.4 & 10.6 & 18.1 \\
\hline Commercial and Industrial & 12.6 & 10.0 & 10.7 & 10.6 & 6.8 & 13.3 \\
\hline Docks & 12.4 & 12.4 & 1.3 & 11.3 & 12.2 & 2.6 \\
\hline Finance & 7.8 & 6.0 & 7.0 & 4.5 & 3.4 & 3.8 \\
\hline Gas Light and Waterworks & 9.7 & 6.8 & 9.0 & 9.0 & 3.6 & 12.2 \\
\hline Insurance & 9.2 & 5.1 & 12.8 & 3.5 & 2.9 & 3.0 \\
\hline Iron, Coal and Steel & 14.4 & 10.0 & 12.9 & 12.5 & 9.0 & 10.8 \\
\hline Mines & 10.8 & 6.8 & 9.9 & 8.3 & 4.9 & 10.1 \\
\hline Mortgage and Land & 9.2 & 5.4 & 10.5 & 7.2 & 4.2 & 9.9 \\
\hline Spinning and Weaving & 7.3 & 4.9 & 5.9 & 8.4 & 8.9 & 6.6 \\
\hline Steamships & 11.2 & 6.5 & 14.4 & 11.2 & 5.7 & 15.7 \\
\hline Tea and Coffee & 10.7 & 9.4 & 6.6 & 6.2 & 4.4 & 5.2 \\
\hline Telegraph & 17.7 & 8.8 & 17.0 & 12.7 & 5.9 & 17.0 \\
\hline Tramways & 10.7 & 4.6 & 16.4 & 8.7 & 4.2 & 14.7 \\
\hline Wagon & 8.1 & 6.8 & 5.5 & 6.8 & 6.7 & 5.4 \\
\hline \multicolumn{7}{|l|}{ PANEL B: LOCATION } \\
\hline Domestic & 10.1 & 6.9 & 9.7 & 8.2 & 4.9 & 10.6 \\
\hline Foreign & 11.5 & 6.4 & 13.2 & 9.7 & 5.0 & 13.5 \\
\hline \multicolumn{7}{|l|}{ PANEL C: DECADE } \\
\hline $1850 \mathrm{~s}$ & 5.8 & 5.9 & 3.0 & 3.4 & 3.2 & 2.4 \\
\hline $1860 \mathrm{~s}$ & 11.7 & 7.3 & 10.6 & 7.4 & 4.6 & 9.4 \\
\hline $1870 \mathrm{~s}$ & 10.8 & 7.7 & 9.5 & 7.9 & 4.8 & 8.8 \\
\hline $1880 \mathrm{~s}$ & 10.8 & 7.0 & 12.1 & 8.4 & 4.7 & 11.4 \\
\hline $1890 \mathrm{~s}$ & 10.4 & 6.7 & 10.4 & 9.4 & 5.4 & 11.0 \\
\hline $1900 \mathrm{~s}$ & 8.9 & 5.6 & 10.0 & 10.0 & 5.2 & 16.4 \\
\hline Overall & 10.5 & 6.8 & 10.7 & 8.6 & 4.9 & 11.6 \\
\hline
\end{tabular}

Source: See text. See table 1.

Notes: The industry classification used above is that used by contemporary stock exchange manuals such as the Stock Exchange Official Intelligence and Stock Exchange Yearbook. We follow the categorisation of 
these yearbooks and work backwards so that although breweries may have originally been in the industrial and commercial category in the yearbooks, they are always in a separate category in our sample. 
Table 3

Large Shareholders and Control

\begin{tabular}{|c|c|c|c|c|c|c|}
\hline & \multicolumn{2}{|c|}{$\begin{array}{l}\text { Large Shareholders } \\
\text { Who Were Directors }\end{array}$} & \multicolumn{2}{|c|}{$\begin{array}{c}\text { Large Shareholders } \\
\text { Who Had Same } \\
\text { Surname as Other }\end{array}$} & \multicolumn{2}{|c|}{$\begin{array}{l}\text { Large Shareholder } \\
\text { Surname Is Part of } \\
\text { Company's Name }\end{array}$} \\
\hline & No. & $\%$ & No. & $\%$ & No. & $\%$ \\
\hline \multicolumn{7}{|l|}{ PANEL A: INDUSTRY } \\
\hline Banks & 50 & 45.9 & 18 & 16.5 & 4 & 2.8 \\
\hline Breweries & 26 & 42.6 & 11 & 18.0 & 11 & 29.7 \\
\hline Commercial and Industrial & 92 & 39.0 & 52 & 22.0 & 50 & 20.1 \\
\hline Docks & 2 & 66.7 & 1 & 33.4 & 0 & 0.0 \\
\hline Finance & 5 & 29.4 & 0 & 0.0 & 0 & 0.0 \\
\hline Gas Light and Waterworks & 11 & 35.5 & 2 & 6.5 & 0 & 0.0 \\
\hline Insurance & 11 & 34.4 & 1 & 3.1 & 0 & 0.0 \\
\hline Iron, Coal and Steel & 29 & 50.0 & 7 & 12.1 & 9 & 13.4 \\
\hline Mines & 16 & 32.7 & 3 & 6.1 & 0 & 0.0 \\
\hline Mortgage and Land & 20 & 23.5 & 6 & 7.1 & 0 & 0.0 \\
\hline Spinning and Weaving & 9 & 75.0 & 3 & 25.0 & 5 & 14.3 \\
\hline Steamships & 18 & 52.9 & 7 & 20.6 & 0 & 0.0 \\
\hline Tea and Coffee & 1 & 11.1 & 0 & 0.0 & 0 & 0.0 \\
\hline Telegraph & 1 & 5.6 & 0 & 0.0 & 0 & 0.0 \\
\hline Tramways & 8 & 23.5 & 2 & 5.9 & 0 & 0.0 \\
\hline Wagon & 7 & 46.7 & 0 & 0.0 & 1 & 7.1 \\
\hline \multicolumn{7}{|l|}{ PANEL B: LOCATION } \\
\hline Domestic & 246 & 44.2 & 99 & 17.8 & 77 & 9.2 \\
\hline Foreign & 60 & 24.3 & 14 & 5.7 & 3 & 0.9 \\
\hline \multicolumn{7}{|l|}{ PANEL C: DECADE } \\
\hline $1850 \mathrm{~s}$ & 2 & 100.0 & 0 & 0.0 & 0 & 0.0 \\
\hline $1860 \mathrm{~s}$ & 36 & 45.6 & 6 & 7.6 & 13 & 8.3 \\
\hline $1870 \mathrm{~s}$ & 13 & 40.6 & 1 & 3.1 & 6 & 5.2 \\
\hline $1880 \mathrm{~s}$ & 119 & 41.2 & 44 & 15.2 & 30 & 11.2 \\
\hline $1890 \mathrm{~s}$ & 88 & 36.7 & 36 & 15.0 & 29 & 13.3 \\
\hline $1900 \mathrm{~s}$ & 48 & 29.8 & 26 & 16.1 & 2 & 1.7 \\
\hline Overall & 306 & 38.1 & 113 & 14.1 & 80 & 9.0 \\
\hline
\end{tabular}


Source: See text. See table 1 for ownership sources. Directors were obtained from Burdett's Official Intelligence, Stock Exchange Official Intelligence and Stock Exchange Year-book.

Notes: The industry classification used above is that used by contemporary stock exchange manuals such as the Stock Exchange Official Intelligence. 
Table 4

Large Shareholders' Socio-occupational Status

\begin{tabular}{|c|c|c|c|c|c|c|}
\hline & \multirow{4}{*}{$\begin{array}{r}\text { All } \\
\text { Companies }\end{array}$} & \multirow{4}{*}{$\begin{array}{l}\text { Average } \\
\text { Value of } \\
\text { Holding } \\
(£ 000 s)\end{array}$} & \multirow{4}{*}{$\begin{array}{c}\text { Domestic } \\
\text { Companies }\end{array}$} & \multirow{4}{*}{$\begin{array}{c}\text { Average } \\
\text { Value of } \\
\text { Holding } \\
(£ 000 s)\end{array}$} & \multirow{4}{*}{$\begin{array}{r}\text { Foreign } \\
\text { Companies }\end{array}$} & \multirow{4}{*}{$\begin{array}{l}\text { Average } \\
\text { Value of } \\
\text { Holding } \\
(£ 000 \text { s) }\end{array}$} \\
\hline & & & & & & \\
\hline & & & & & & \\
\hline & & & & & & \\
\hline Gentlemen & 327 & 15.6 & 220 & 12.4 & 107 & 23.3 \\
\hline Merchant & 252 & 14.6 & 176 & 13.3 & 76 & 17.6 \\
\hline Manufacturer & 124 & 23.9 & 118 & 23.6 & 6 & 29.3 \\
\hline Unclassified males & 124 & 23.5 & 80 & 23.1 & 44 & 24.4 \\
\hline Institution & 49 & 52.6 & 23 & 47.0 & 26 & 57.6 \\
\hline Professionals & 43 & 8.6 & 35 & 7.7 & 8 & 13.7 \\
\hline Banker & 41 & 14.2 & 31 & 8.7 & 10 & 27.0 \\
\hline Legal Profession & 41 & 9.6 & 31 & 10.0 & 10 & 8.4 \\
\hline Women & 35 & 13.5 & 33 & 9.9 & 2 & 34.5 \\
\hline Politician & 28 & 10.1 & 15 & 11.6 & 13 & 8.5 \\
\hline Nobility & 20 & 132.7 & 14 & 199.8 & 6 & 9.8 \\
\hline Army and naval officers & 16 & 14.8 & 12 & 10.5 & 4 & 25.8 \\
\hline Stockbroker & 14 & 10.9 & 9 & 12.6 & 5 & 5.7 \\
\hline Other Finance & 13 & 5.8 & 12 & 5.9 & 1 & 5.0 \\
\hline Retailer & 12 & 16.2 & 12 & 16.2 & 0 & 0.0 \\
\hline White collar & 9 & 9.8 & 8 & 10.8 & 1 & 10.0 \\
\hline Clergy & 5 & 7.3 & 3 & 7.4 & 2 & 14.3 \\
\hline Agriculture & 3 & 3.1 & 2 & 1.3 & 1 & 6.8 \\
\hline \multirow[t]{2}{*}{ Trustees } & 2 & 11.3 & 1 & 10.0 & 1 & 1.3 \\
\hline & 1,158 & 19.5 & 835 & 18.3 & 323 & 22.7 \\
\hline
\end{tabular}

Source: see text. . see table 1.

Notes: Average value of holding is based on the par value of shares. 
Table 5

Wealth of Large Shareholders

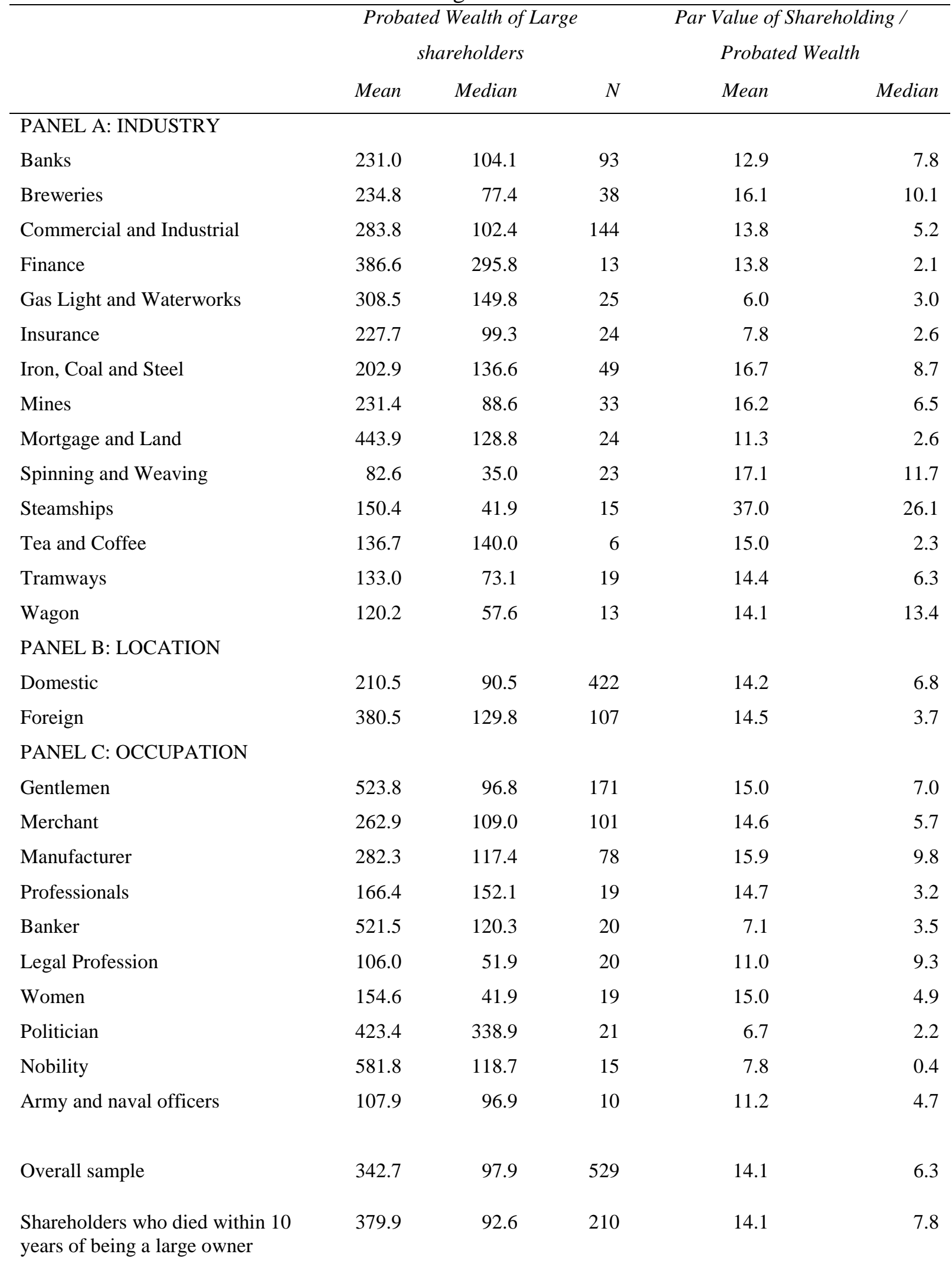


Shareholders who died within 2

222.5

84.7

68

15.2

10.0 years of being a large owner

Sources: see table 1 for ownership sources. Probated wealth data are from the Will Calendars in Ancestry.com.

Note: This table excludes 52 shareholders whose probated wealth was less than the paid-up value of their shareholding. O'Donoghue et al., "Composite Price Index" is used to convert probate values into 1900 values. The industry and occupations panels do not add up to 529 as not all industries or occupations are included. 
Table 6

Large Owners Who Were Millionaires (1900 prices)

\begin{tabular}{|c|c|c|c|c|c|}
\hline $\begin{array}{l}\text { Name [Year of } \\
\text { death] }\end{array}$ & $\begin{array}{l}\text { Occupation } \\
\text { (Occupation } \\
\text { as given in } \\
\text { ODNB or } \\
\text { elsewhere) } \\
\end{array}$ & Residence & $\begin{array}{l}\text { Wealth } \\
£ m \\
(1900 \\
\text { prices })\end{array}$ & $\begin{array}{l}\text { Par value of } \\
\text { shareholding } \\
\text { / wealth (\%) }\end{array}$ & Companies \\
\hline $\begin{array}{l}\text { Charles Morrison } \\
\text { [1909] }\end{array}$ & $\begin{array}{l}\text { Gentleman } \\
\text { (Merchant } \\
\text { banker) }\end{array}$ & London & 10.6 & 1.1 & $\begin{array}{l}\text { Amazon Telegraph; } \\
\text { Emerald and Phoenix } \\
\text { Brewery; Tramways } \\
\text { Union; United Asbestos } \\
\text { Co. }\end{array}$ \\
\hline $\begin{array}{l}\text { James Williamson } \\
\text { (Lord Ashton) } \\
\text { [1930] }\end{array}$ & $\begin{array}{l}\text { Linoleum } \\
\text { manufacturer }\end{array}$ & Lancashire & 5.0 & 0.2 & San Sebastian Nitrate \\
\hline $\begin{array}{l}\text { Thomas Brassey } \\
\text { [1871] }\end{array}$ & Contractor & London & 3.0 & 0.3 & $\begin{array}{l}\text { Central Argentine Land } \\
\text { Co. }\end{array}$ \\
\hline $\begin{array}{l}\text { Joseph T. Mills } \\
\text { [1924] }\end{array}$ & Landed gentry & Norfolk & 2.0 & 0.2 & Cagliari Gas and Water \\
\hline $\begin{array}{l}\text { Baron John H. } \\
\text { Schroder [1910] }\end{array}$ & Banker & London & 2.0 & 0.8 & Amelia Nitrate \\
\hline $\begin{array}{l}\text { Thomas V. Smith } \\
\text { [1906] }\end{array}$ & Distiller & London & 1.9 & 0.0 & $\begin{array}{l}\text { Smith Garrett and Co. } \\
\text { (Brewery) }\end{array}$ \\
\hline $\begin{array}{l}\text { George Grenfell } \\
\text { Glyn } \\
\text { (Lord Wolverton) } \\
{[1889]}\end{array}$ & Banker & London & 1.9 & 0.3 & $\begin{array}{l}\text { Palmer's Shipbuilding and } \\
\text { Iron }\end{array}$ \\
\hline $\begin{array}{l}\text { Michael T. Bass } \\
\text { [1884] }\end{array}$ & Brewer & Staffordshire & 1.9 & 0.8 & $\begin{array}{l}\text { National Discount } \\
\text { Company }\end{array}$ \\
\hline $\begin{array}{l}\text { George Wythes } \\
\text { [1883] }\end{array}$ & Contractor & London / Kent & 1.5 & 13.4 & $\begin{array}{l}\text { Bank of Queensland; } \\
\text { Central Argentine Land } \\
\text { Co; New British Iron; } \\
\text { Rhymney Iron }\end{array}$ \\
\hline $\begin{array}{l}\text { Ludwig Loeffler } \\
\text { [1906] }\end{array}$ & $\begin{array}{l}\text { Gentleman } \\
\text { (Inventor and } \\
\text { businessman) }\end{array}$ & London & 1.5 & 2.4 & Copiapo (Mining) \\
\hline $\begin{array}{l}\text { Sydney Stern (Lord } \\
\text { Wandsworth) } \\
\text { [1912] }\end{array}$ & Banker & London & 1.4 & 3.2 & Indianapolis (Brewery) \\
\hline $\begin{array}{l}\text { Thomas H. Ismay } \\
\text { [1899] }\end{array}$ & Ship Owner & Lancashire & 1.4 & 0.1 & Platte Land \\
\hline $\begin{array}{l}\text { George Herring } \\
{[1906]}\end{array}$ & $\begin{array}{l}\text { Gentleman } \\
\text { (Businessman) }\end{array}$ & London & 1.4 & 0.8 & London \& Yorkshire Bank \\
\hline $\begin{array}{l}\text { James C. Eno } \\
{[1915]}\end{array}$ & $\begin{array}{l}\text { Gentleman } \\
\text { (Chemist) }\end{array}$ & London & 1.3 & 0.6 & Tyne Steam Shipping \\
\hline Henry Tate [1909] & $\begin{array}{l}\text { Sugar } \\
\text { merchant }\end{array}$ & London & 1.3 & 0.5 & Hotchkiss Ordinance \\
\hline $\begin{array}{l}\text { Samuel Fielden } \\
\text { [1889] }\end{array}$ & $\begin{array}{l}\text { Gentleman } \\
\text { (Cotton } \\
\text { manufacturer) }\end{array}$ & Lancashire & 1.3 & 0.4 & Union Plate Glass \\
\hline
\end{tabular}




\begin{tabular}{|c|c|c|c|c|c|}
\hline $\begin{array}{l}\text { Christian Allhusen } \\
\text { [1890] }\end{array}$ & $\begin{array}{l}\text { Gentleman } \\
\text { (Chemical } \\
\text { manufacturer) }\end{array}$ & $\begin{array}{l}\text { Buckinghamsh } \\
\text { ire }\end{array}$ & 1.2 & 8.6 & $\begin{array}{l}\text { Newcastle Chemical } \\
\text { Works }\end{array}$ \\
\hline $\begin{array}{l}\text { William C. Quilter } \\
\text { [1911] }\end{array}$ & $\begin{array}{l}\text { Stock broker / } \\
\text { M.P. }\end{array}$ & London & 1.2 & 2.1 & $\begin{array}{l}\text { Lion Fire (Insurance); } \\
\text { United Telephone }\end{array}$ \\
\hline $\begin{array}{l}\text { Davison Dalziel } \\
\text { [1928] }\end{array}$ & $\begin{array}{l}\text { Gentleman } \\
\text { (Newspaper } \\
\text { proprietor and } \\
\text { financier) }\end{array}$ & London & 1.2 & 1.2 & Aux Classes Laborieuses \\
\hline $\begin{array}{l}\text { Henry Silver } \\
{[1910]}\end{array}$ & $\begin{array}{l}\text { Gentleman } \\
\text { (Journalist) }\end{array}$ & London & 1.1 & 0.9 & Bank of South Australia \\
\hline $\begin{array}{l}\text { Everard A. Hambro } \\
\text { [1925] }\end{array}$ & $\begin{array}{l}\text { Merchant } \\
\text { banker }\end{array}$ & London & 1.1 & 2.9 & Santa Fe Land \\
\hline $\begin{array}{l}\text { F. W. Isaacson } \\
{[1898]}\end{array}$ & $\begin{array}{l}\text { M.P. } \\
\text { (Silk and coal } \\
\text { merchant) }\end{array}$ & London & 1.1 & 0.3 & $\begin{array}{l}\text { Edinburgh United } \\
\text { (Brewery) }\end{array}$ \\
\hline James Stern [1901] & Banker & London & 1.1 & 1.3 & Imperial Bank \\
\hline $\begin{array}{l}\text { George F. Muntz } \\
\text { [1898] }\end{array}$ & $\begin{array}{l}\text { Metal } \\
\text { manufacturer }\end{array}$ & $\begin{array}{l}\text { Worcestershir } \\
\mathrm{e}\end{array}$ & 1.0 & 3.4 & $\begin{array}{l}\text { Birmingham Joint Stock } \\
\text { Bank; Muntz's Metal Co. }\end{array}$ \\
\hline
\end{tabular}

see table 5 .

Note: In the case where someone is a large owner in two or more companies, the value reported in the fifth column is the sum of the par value of shareholding/wealth ratios. ODNB is the Oxford Dictionary of National Biography. Isaacson's occupation outside of Parliament was obtained from Alex Windscheffel, Popular Conservatism in Imperial London, 1868-1906 (London, 2007), 112. 